\title{
Pragmatist Perspective on Knowledge and Knowledge Management in Organizations
}

\author{
Linh-Chi Vo \\ Correspondence: Linh-Chi Vo, School of Management, ISC Paris, 22 bl du Fort de Vaux, 75017, Paris, France. \\ E-mail: linh-chi.vo@iscparis.com
}

Received: May 26, 2012

Accepted: June 25, 2012

Online Published: August 8, 2012

doi:10.5539/ibr.v5n9p78

URL: http://dx.doi.org/10.5539/ibr.v5n9p78

\begin{abstract}
Three main schools of thought about knowledge and knowledge management are positivism, non-positivism, and pluralistic perspective. Their conflict about what knowledge is and what knowledge management endures without concluding end. This article contributes to the literature by arguing for a different perspective that helps solve this conflict: pragmatism. Knowledge, for pragmatists, is outcome of inquiry, with the chief value being its usefulness. From this perspective, we argue for a reflective knowledge management approach, which requires knowing people and people in charge of the knowledge management function to have an attitude of being that is called knowledge responsibility.
\end{abstract}

Keywords: knowledge, knowledge management, pragmatism

\section{Introduction}

Among many developments taking place recently in the field of management and organization, the movement emphasizing the role of knowledge is remarkable (Schipper, 2005). With the emergence of the "knowledge-based view of the firm" (Grant, 1996), knowledge has become a new production factor that outweighs the traditional ones of land, labor, and capital (Drucker, 1993; de Geus, 1997). Because of its impact, it is often argued that the development of knowledge must not be left to chance, but should be systematically managed (Schipper, 2005). In fact, the literature of knowledge management has developed quickly and the topic has demonstrated increasing diversity and specialization (Easterby-Smith \& Lyles, 2003). Knowledge management has also become a term commonly used in today's business environment and has been usually associated with large-budget projects (de Geus, 1988). Many firms have explicitly recognized the role of knowledge management by including "knowledge manager" or "Chief Knowledge Officer" in their organizational charts (Johnson, 2000).

Knowledge is not a simple and concrete subject and ideas concerning knowledge management cannot be discussed without the introduction of epistemological themes (Schipper, 2005). Philosophers, theoreticians and practitioners alike have been deliberating the nature of knowledge for years. The quest for knowledge in different scientific paradigms has always been conducted in essentially different belief systems, and different perspectives about knowledge management have developed accordingly. We can identify three main schools of thought about knowledge and knowledge management: positivism, non-positivism, and pluralistic perspective. Non-positivism includes constructivism, phenomenology, interpretivism, idealism, and hermeneutics (Jarzabkowski et al., 2010; Wicks \& Freeman, 1998), but the name non-positivism is used here because the development of these paradigms has not come to a stable state (Avenir, 2010; Guba \& Lincoln, 1994). Scholars in pluralistic perspective identify themselves in both positivist and non-positivist schools since they advocate a pluralistic epistemology.

Regardless of these schools of thought, the very meaning of knowledge appears to remain elusive due to a polarization of the varying discourses about knowledge. Critiques about different approaches in knowledge management have been made. The debate continues without a concluding end. With conflicting points of view about knowledge and knowledge management that endure (e.g. Alvesson \& Karreman, 2001), the decline of knowledge management in business organizations is inevitable (Hislop, 2010). Thus, this paper contributes to the literature by arguing for a perspective: the pragmatist philosophy about knowledge and knowledge management. It helps address the gulf and conflict between existing schools of thought by proposing an encompassing view to eliminate their opposition. 
This article is organized as follows. First, we present the aforementioned schools of thought about knowledge and knowledge management in the literature. We then point out the pitfalls in each perspective and the problems of maintaining their meaningless opposition. This section is followed by a presentation of our methodology. We then start our discussion of the pragmatist perspective about knowledge and knowledge management. To this end, we render our pragmatist-inspired interpretations of knowledge by heavily drawing on John Dewey. In light of this discussion, we present the pragmatist view about knowledge management, which can be named reflective knowledge management (Schipper, 2005). The article ends with a conclusion.

\section{Knowledge and Knowledge Management in the Literature}

A passionate debate about what knowledge is and what forms or types of it are available can be identified in the literature. One can distinguish the positivist and non-positivist perspectives in this debate. It is important to note that the distinction between these two standpoints has been made by using different labels such as positivist versus constructivist (Vera \& Crossan, 2003), perceptive and cognitive versus social and constructionist, possession versus process, or cognitive-possession versus social-process (Chiva \& Alegre, 2005). We also observed that many scholars adopt a pluralistic epistemology and identify themselves with both schools of thought. As different views of knowledge lead to different perceptions of knowledge management (Alavi \& Leider, 2001), three different perspectives about knowledge management have developed accordingly. In this section, we will discuss these three perspectives about knowledge and knowledge management.

\subsection{Positivist Perspective about Knowledge and Knowledge Management}

According to Spender (1996a) and Chiva and Alegre (2005), followers of positivist school believe that knowledge is justified true belief. They all share the idea of knowledge as perceptive and as a commodity. Thus, emphasis is placed on the possession of knowledge. Knowledge is defined as a collection of representations of the world that is made up of a number of objects and events. This school posits that knowledge is universal and, hence, two cognitive systems should come up with the same representation of the same objects or situations. It is free from the influences of any subjective assumptions that may distort the reality (Taylor, 2006). Knowledge is assumed to take an explicit form, adhering to an objectivity that enables organizational researchers to represent the way the world actually is (Aram \& Salipant, 2003) not from a place within it, but from nowhere in particular (Zundel \& Kokkalis, 2010). Thus, it is possible to codify, store and transmit knowledge between people. Learning, in this perspective, is the improvement of representations.

The conventional wisdom of this school of thought is that knowledge exists prior to and independently from the knowing subject, who creates no knowledge in the act of appropriation (Chiva \& Alegre, 2005). Knowledge methodologically precedes its application in specific circumstances in the organizational (Donaldson, 1996). It is assumed to be translatable into actions that help solve practical problems and advance organizational practice (Tranfield \& Starkey, 1998). Seen from this perspective, knowledge precedes action and is distinguishable from action (Jarzabkowski et al., 2010).

In this perspective, knowledge management is defined as "the explicit control and management of knowledge within an organization aimed at achieving the company's objectives”, "the formal management of knowledge for facilitating creation, access, and reuse of knowledge, typically using advanced technology", "the process of creating, capturing, and using knowledge to enhance organizational performance", or "the ability of organizations to manage, store, value, and distribute knowledge" (Vera \& Crossan, 2003). The goal of knowledge management is to capture, codify and distribute organizational knowledge via the application of information and communication technologies so that it can be shared by all employees. It focuses on knowledge use, not knowledge creation. The target of all investments in knowledge management is the individual workers and the extent to which he or she has access to, and can leverage - information needed to get the job done (McElroy, 2000).

\subsection{Non-positivist Perspective about Knowledge and Knowledge Management}

In the study of knowledge, although the positivist school is the predominant one, it has been increasingly challenged and complemented by the non-positivist school (Vera \& Crossan, 2003), shifting the notion of knowledge as a commodity that individuals or organizations may acquire to the study of knowledge as socially constructed and held collectively in organizations. This school proposes the idea that reality is socially constructed or conceived and is based on social interactions and discursive behaviours (Chiva \& Alegre, 2005). The only kind of reality we can consciously know is constituted by the kind of distinctions we make in language (Heaton \& Taylor, 2002). When people live in different operational contexts, they perceive different realities. This approach understands knowledge as not as a representation, but a constructing or creating acts, in other words, as a process. It is something which we do, not something that we possess (Chiva \& Alegre, 2005). 
The notions of practice and communities of practice are very important in this school of thought. A community of practice is "a set of relations among persons, activity, and world, over time" (Lave \& Wenger, 1991). The participants are united in both action and in the meaning that action has, both for themselves and for the larger collective (Lave \& Wenger, 1991). The practice of a community of practice is the specific knowledge that the community members develop, share and maintain. It can contain ideas, information, documents, or styles that community members share (Wenger, McDermott, \& Snyder, 2002). It is "the way in which work gets done and knowledge is created" (Brown \& Duguid, 1998, 2001), or "the coordinated activities of individuals and groups in doing their "real work" as it is informed by a particular organizational or group context" (Cook \& Brown, 1999).

Knowledge is defined as embedded in situated practices of individual (Gherardi, 2000). "Practice articulates knowledge in and about organizing as practical accomplishment, rather than as a transcendental account of decontextualized reality" (Gherardi, 2000). Moreover, knowledge is situated in the historical, social and cultural contexts in which it arises and embodied in a variety of forms and media. It is acquired through some form of participation, and it is continually reproduced and negotiated (Nicolini, Gherardi, \& Yanow, 2003).

In this perspective, scholars have developed different concepts to better indicate the practice-based nature of knowledge. Brown and Duguid (1998) elaborated the distinction between "know-how" and "know-what". Know-what is something people carry around in their head and pass between each other. It embraces the ability to put knows-what into practice. Know-how is produced and held in particular communities of practice. Cook and Brown (1999) critiqued the positivist school for viewing knowledge as something to be used in action and not as part of action. They argued for a perspective that does not treat these as separate or separable, a perspective that focuses on the knowledgeability of action, that is on knowing (a verb connoting action, doing, practice) rather than knowledge (a noun connoting thing, elements, facts, processes). Orlikowski (2002) developed the notion of organizational knowing as a substitution for the notion of organizational knowledge. It emerges from the ongoing and situated actions of organizational members as they engage the world.

Learning is, thus, the participation and interaction in communities of practice. The content of learning in this perspective is the identity formation at work (Elkjaer, 2004), in other words, becoming old-timer in a community of practice (Lave \& Wenger, 1991). The distinction between learning and knowledge disappears (Chiva \& Alegre, 2005).

Overall, the non-positivists all agree on the assumption that the inquirer and the phenomenon under inquiry cannot be separated in the knowledge process. They critique the positivist viewpoint that knowledge precedes action. The construction of knowledge is rooted in practice and the development of theory is a systematic extension of practice (Scherer \& Steinmann, 1999 in Jarzabkowski et al., 2010). We cannot know an independent, objective world that stands apart from our experience of that world (Avenir, 2010).

In this perspective, knowledge management scholars acknowledge the importance of communication and social interaction processes that will allow knowledge sharing to occur (Hislop, 2009). Critiques have been mounted of the positivist perspective precisely on the grounds that it ignores the social architecture of knowledge exchange within organizations (Easterby-Smith \& Lyles, 2003) and completely side-steps the question of how knowledge is created, disseminated, renewed and applied (Cavaleri, 2004; McElroy, 2000). To this end, developing communities of practice has been viewed as a popular approach for knowledge management because they favour situated and context-dependent learning and knowledge creation (Wenger, 2004). Scholars believes that we can manage knowledge by promoting social networks and the cultivation of trust, norms and shared values amongst employees that constitute communities of practices (Bresnen et al., 2003).

\subsection{Pluralistic Perspective about Knowledge and Knowledge Management}

Some authors have tried to provide an alternative perspective that combine both positivist and non-positivist schools. They propose that organizations have different types of knowledge, and that identifying and examining these will lead to more effective means for generating, sharing, and managing knowledge (Orlikowski, 1996). As a result, classifications of knowledge have been developed and then used to examine the various strategies and techniques, through which different types of knowledge are created, codified, converted, transferred, and exchanged. A well-known typology of knowledge is the distinction between explicit and tacit knowledge put forward by Nonaka (1994) based on the work of Polany. Explicit knowledge refers to knowledge that is transmittable in formal, systematic language. Tacit knowledge has a personal quality, which makes it hard to formalize and communicate. Explicit knowledge can be converted to tacit knowledge and vice versa. Spender (1996b) adopted a pluralistic epistemology to capture different types of knowledge that organizations make use of. For him, knowledge can be held by an individual or a collectivity. It can also be explicit or implicit. Thus, there are four types of knowledge: conscious, objectified, automatic, and collective. The first three types of 
knowledge take the same idea of knowledge as perceptive and as a commodity while the last type indicates that knowledge is socially constructed. Similarly, for Kogut and Zander (1992), knowledge of the firm must be understood as socially constructed. However, they still point out that one property of knowledge is the degree of codifiability and coded knowledge is alienable from the individual who codified it. Alavi and Leider (2001) concluded from their review of the literature that knowledge can be referred to as declarative, procedure, causal, conditional, and relational. Additional knowledge taxonomies such as local versus universal, codified versus uncodified, canonical versus non canonical, have also been elaborated (Tsoukas, 1996).

This perspective alludes to the distinction between two positivist and non-positivist perspectives and state that we should approach the tasks associated with knowledge management by using two distinct strategies: a codification strategy centered on information technology and its associated resources and a personalization strategy centered on managing people and developing communities of practice (Hansen et al., 1999). Sanchez (2005) also says that both approaches of knowledge management are likely to be needed in any organization. Each approach has its own advantages and disadvantages. The objective for knowledge managers is therefore to create a knowledge management strategy that synthesizes the right combination and balance of the two.

\section{Critique of the Perspectives and Their Opposition}

The above perspectives about knowledge and knowledge management and their opposition bear some important critiques, which will be presented in this section.

Although the non-positivist scholars have pointed out a certain inadequacy of the conceptualization of knowledge in the positivist perspective, they have not offered a well-founded alternative. The proliferation of different varieties of constructivist perspectives generates enormous confusion, which is not favourable to knowledge development (Avenir, 2010). Moreover, it has been claimed that the constructivists critiques the positivist ones but unwittingly retain the assumptions behind it. Rather than moving beyond such assumptions, the constructivists simply invert them (Wicks \& Freeman, 1998). That is, while positivism aims at finding and describing knowledge, constructivists worry about creating knowledge. The emphasis shifts from finding the right knowledge to making lots of new and different types of knowledge. By admitting that knowledge is one-sided, partial, and subjective, the non-positivist perspective is trapped in the problem of how much or what kinds of knowledge are used. It is from this perspective that relativism (which means that all methods, insights, points of view, and moral values are equally valid) becomes a fundamental problem. "Researchers are caught in a web of subjective activities where they only get a partial and distorted glimpse of reality. They continue to be troubled by their inability to fully know reality and apologize for the bias and subjectivity of their work rather than rejecting positivist notions of objectivity altogether” (Wicks \& Freeman, 1998, p. 128).

Moreover, non-positivist perspective has not provided any feasible approach to knowledge management. The notion of community of practice itself is problematic. Many authors have pointed out the ambiguous or ill-defined aspects of the notion (Handley et al., 2006; Robet, 2006). It has become popular in knowledge management literature because it marks the passage from a cognitive and individual vision of knowledge and learning to a social and situated one. It encompasses a plurality of concepts related to the practice perspective: for instance, the situatedness and sociality of practices, the central importance of practical know-how for work, the existence of collective identities, and the importance of learning processes within a community of practitioners (Corradi, Gherardi \& Verzelloni, 2010). From the practice perspective, communities of practice are just one of the forms of organizing. Referring to a community of practice is not a way to postulate the existence of a new informal grouping or social system within the organization, but is a way to emphasize that every practice is dependent on social processes through which it is sustained and perpetuated, and that learning takes place through the engagement in that practice (Gherardi, Nicolini, \& Odella, 1998).

The conflict between positivism and non-positivism has resulted in what Alvesson and Karreman (2001) described as "inconsistent, vague, broad, two-faced, and unreliable" concept of knowledge. Thus, it is understandable that most literature on knowledge management and/or organizational knowledge creation tends to treat management as something that is either self-evident, unproblematic or black-boxed, unexplicated (Alvesson \& Karreman, 2001). Ten years later, from a review of academic work on organizational knowledge creation, Nonaka and von Krogh (2009) found that the debate between these perspectives still continues, resulting in unanswered questions about knowledge and knowledge creation. The authors suggested how the controversies might be resolved by reiterating their pluralistic perspective and upholding the Nonaka's (1994) conceptualization of tacit and explicit knowledge, which themselves are not without critiques (Tsoukas, 1996).

The pluralist perspective can also be critiqued for considering tacit and explicit knowledge as two separate types of knowledge (Tsoukas, 1996). Nonaka (1994) and Nonaka and von Krough (2009) argued that tacit and explicit 
knowledge are not separate to the extent that the two types are "mutually complementary" in their dynamic interaction with each other in activities by individuals and groups. However, tacit knowledge is the necessary nature of all knowledge, the tacit and explicit nature of knowledge is inseparably related (Tsoukas, 1996). According to Tsoukas (1996), for such taxonomic thinking to be possible, the conceptual categories along which the phenomena are classified must be assumed to be discrete, separate, and stable. The problem is that they hardly ever are.

In their attempt to resolve the controversies between existing perspectives on knowledge and knowledge management, Nonaka and von Krough (2009) mentioned briefly about the philosophy of pragmatism but did not discuss in detail their potential contribution to the debate.

\section{Methodology}

In order to deal with these controversies, we adopt a theoretical methodology rather than an empirical one. We do not conduct field study, but attempt to identify an alternative theoretical foundation that can replace or bridge the divide between the existing perspectives about knowledge and knowledge management.

There are several criteria in selecting an alternative theoretical foundation: it should be able to transcend competing assumptions about the knowledge of positivist and non-positivist paradigms; it should provide direction on how knowledge should be managed effectively. These criteria can be termed the philosophical challenge and empirical challenge, respectively.

The search for an alternative theory starts with an overview of different philosophies that are known to discuss about knowledge and/or learning. We include the philosophies about learning in our search because learning and knowledge are inter-related. Discussion of knowledge is always related to that about learning and vice versa. We then classify the philosophies into three categories: positivist, non-positivist, and others. The category "others" refers to the philosophies that have links with both positivism and non-positivism. From our search, we come to identify the pragmatist philosophy of John Dewey as an appropriate theoretical perspective that may help us address our problematic and heated debates between different camps of knowledge and knowledge management.

In the next sections, we will present the pragmatist view of knowledge and knowledge management and discuss how it can help resolve the existing controversies.

\section{Knowledge through the Pragmatist Perspective}

\subsection{Pragmatism: A Short Introduction}

Before discussing the concept of knowledge from pragmatist perspective, it is worth mentioning the notions of experience, situation, and inquiry that are conceptualized by John Dewey. For Dewey, an individual is a being interacting with an environment. Dewey's perspective on the relationship between the individual and the environment is configured by his concept of experience (1958). Our experience includes something had, an undergoing of things which "happen to us", and responsive "taking". Experiencing is about suffering and enjoyment, about the feeling of need and the making of effort, while what is experienced is anything which can occur to anyone (Dewey, 1916). There are times when the ongoing individual-environment interaction breaks down. Ongoing action is interrupted. Dewey terms these instances problematic situations. The problematic of a situation initiates inquiry. Inquiry is reflective problem-solving which changes the problematic situation into a determinate one (Dewey, 1938). The process of inquiry consists of the cooperation of two kinds of operations: existential (the actual transformation of the situation) and conceptual (reflection or thinking) (Dewey, 1938). In inquiry, the problem of the situation and its possible solution are progressively determined with reference to future consequences. The first step toward the identification of problem lies in the collection of facts. These facts help formulate the hypothesis about the problem and possible solution. The hypothesis articulates a relationship between actions and consequences on the basis of a hypothetical interpretation of the problem and possible solution. The hypothesis is not sufficient to deal with problematic situation. The individual needs action to actually test the hypothesis. If the action indeed has the expected result, a unified situation has been created and the process of inquiry comes to an end (Dewey, 1938). In a sense we could say that the occurrence of a unified situation proves that the hypothesis was correct or warranted (Biesta \& Burbules, 2007).

\subsection{Knowledge Seen through a Pragmatist Lens}

In this perspective, knowledge is defined as being the outcome of inquiry (Dewey, 1938). This conceptualization of knowledge encompassed both positivist and non-positivist perspectives. First, there is generalized knowledge, such as the kind of knowledge that explains why turning a handle causes the door to open (Polkinghoime, 2000). It is the convergent and cumulative effect of perpetual inquiry that defines knowledge in its generalized meaning (Biesta \& Burbules, 2007). However, knowledge is not a mirror of reality and the role of science is not to make 
knowledge as true as possible so it represents reality in an accurate way (Fenstermacher \& Sanger, 1998). There is not, on the one hand, knowledge and, on the other, the real world. Second, the context-dependent and personal nature of knowledge is acknowledged. However, knowledge is not a construction of the human mind, but a construction that is located in the transaction between us and the environment (Biesta \& Burbules, 2007).

It can be said that pragmatists move beyond the polarization of knowledge as universal versus situated between positivism and non-positivism. Moreover, unlike the pluralistic perspective, they do not see universal /explicit and situated/tacit knowledge as two separated types interacting along the continuum (Nonaka \& von Krogh, 2009). They see all knowledge as having both particularizing and generalizing functions working together (Dewey, 1916). A confused situation has to be cleared up by resolving it into sharply defined details. Without the particulars identified in our transactions with the environment, there is no material for knowing and no intellectual growth. Without placing these particulars in the context of the meanings brought out in the larger experience of the past, particulars are meaningless.

Pragmatism regards knowledge as provisional. As the outcome of inquiry, knowledge is always related to the settlement of a particular situation by a particular inquiry. There is no guarantee that the conclusion reached by it will always remain settled (Dewey, 1938). Theoretically speaking, all particular conclusions of specific inquiries are components of an enterprise that is continually renewed (Biesta \& Burbules, 2007). Moreover, knowledge cannot be subjected to universally valid interpretations. Instead, pragmatists advocate multiple interpretations of events. Pragmatic inquiry concerns itself with the identification of various standpoints, in order to view a problem in more detail, and from different angles (Metcalfe, 2008). Somewhat provocatively, pragmatists consider the sole focus on generalizing and generalized knowledge as counter-productive and illogical (Dewey, 1938).

Pragmatists would share with non-positivists the argument that knowledge is embedded in situated practices of individual. Their view about knowledge and action is that they are undivided in a totality. But they also emphasize the role of thought and reflection in generating new knowledge. Thought and reflection are significant to inquiry (Dewey, 1938). Explicit actions enable us to determine the worth and validity of our reflective considerations. Without observable actions, we have at most a hypothesis about a problem and its solution. In order to gain knowledge, we need action (Dewey, 2005). Action, however, does not qualify as the sole prerequisite for knowledge. Knowing, then, is not the possession of knowledge. It is not something that takes place inside the human mind (Biesta \& Burbules, 2007). Knowing is itself an activity. "Knowing consists of operations that give experienced objects a form in which the relations, upon which the onward course of events depends, are securely experienced” (Dewey, 2005, p. 295).

From a pragmatist perspective, the chief value of knowledge is its usefulness as an organizing device with which to solve social and organizational problems, thereby improving the working, living, and social conditions of communities (Dewey, 1927). The usefulness of knowledge is an important criterion to differentiate between meaningful and not meaningful knowledge (Dewey, 1931). Dewey argues that it is not the possibility of knowledge, but its point - the uses we make of it - that must occupy our inquiries into its nature (Dewey, 1972). This principle is further explicated by what James (1907/1910) in Metcalfe (p. 1094, 2008) wrote: "what works best in a particular situation".

\section{Implications for Knowledge Management from the Pragmatist Perspective}

The positivist and non-positivist perspectives in knowledge management are often considered as the first and the second generations of knowledge management (McElroy, 2000), reflecting the dominance of the former in the past and the increasingly influence of the latter in recent years.

From the pragmatist epistemology of knowledge, we argue for an approach of knowledge management that can be called reflective knowledge management (Schipper, 2005). Reflective knowledge management embraces the both positivist and non-positivist schools of knowledge management and shares the point of view of pluralistic perspective of knowledge management. It argues for the participation of all knowing people in the sharing of knowledge and does not deny the role of IT in knowledge management. However, it requires knowing people and people in charge of the knowledge management function to have an attitude of being that can be called knowledge responsibility. There are also some potential pitfalls of existing knowledge management perspectives that reflective knowledge management addresses.

As the chief value of knowledge for pragmatists is its usefulness - useful in the sense of helping people to better cope with the world or to create better organizations, knowledge does not stand on its own but must be intrinsically linked to something else, be it a purpose, a problem, or a common project. Schipper (2005) used the 
term knowledge responsibility to describe this pragmatist feature of knowledge. Knowledge responsibility has two sides. On the one hand, it concerns a responsibility for improving knowledge claims. This means one has to be careful in his/her knowledge claims. It also means that one has to be open to different interpretations of events, acknowledge different concepts and classificatory schemes, and identify various standpoints from which a problem can be viewed in more detail and from different angles (Minnich, 2005). On the other hand, there is a responsibility for the knowledge other people have. When one engages in inquiry to strive for better understanding and improve his/her actual knowledge claims (Dewey, 1938), that person exercises the first side of knowledge responsibility. If this person thinks that some knowledge claims should be known by others as well, it is a manifestation of the second side of knowledge responsibility. To put this responsibility into effect, the constructive criticism of knowledge claims made by others and the real sharing of one's own knowledge and doubts are important means.

"Knowledge management is nothing but the proper exercise of knowledge responsibility" (Schipper, 2005). Schipper did not deny the importance of seeking financial returns on knowledge for business organizations, but argued that the issue would be more properly denoted as the "economics" of knowledge, and the economics of knowledge as such does not necessarily exclude the involvement of knowledge management as the exercise of knowledge responsibility.

Reflective knowledge management as defined is not a novel phenomenon (Schipper, 2005). People always exercise knowledge responsibility amid other activities. Inquiries enter into every area of life and into every aspect of every area in an intimate and decisive way (Dewey, 1938). It is part of life to inquire the world, to mull things over, to make evaluations and draw conclusions. Inquiries may guide actions towards overcoming immediate impediment or direct efforts towards desired outcomes (Dewey, 1938).

What is new is the fact that these kinds of activities are being regarded as a separate management function managed by some CKO or knowledge managers (Schipper, 2005). When a separate knowledge management function is set up, there are some risks that reflective knowledge management as advocated here should be conscious of. They include the risk of a dominant management focus, misplaced universality, collective myopia, and forgotten absence. They will be presented below.

\subsection{Management Focus}

The risk of management focus implies that knowledge is disseminated from a general management perspective, without real attention being paid to the concrete problems and wishes of the people involved and affected (Schipper, 2005). We reiterate one more time that pragmatism advocates usefulness as the criterion of desirable knowledge (Dewey, 1927, 1931). Useful knowledge is differentiated from useless knowledge by its practicality the uses we make of it. Thus, it is important to avoid the pitfall of management focus by keeping in mind that activities which we often label "knowledge management" were originally embedded in the practice of the knowing people themselves. Unreflectively isolating such people from their primary context in terms of a separate management function will trap us in the risk of making knowledge irrelevant and useless (Schipper, 2005).

The importance of avoiding the problem of management focus is implied in the four themes of knowledge that we discussed above. Involving knowing people in reflective knowledge management is needed to ensure their participation in organizations, society and communities and take control of their transactional knowledge. A multi-perspective sharing of knowledge, hence, reciprocity in the organization is achieved only when different people participate in the knowledge processes. From participation and reciprocity, we have the sustainability of democratic knowledge processes. We also need to respect their experience-based knowledge and the fact that everyone's experience is equally real.

\subsection{Misplaced Universality}

As the outcome of inquiry, knowledge does not represent universally valid interpretations (Dewey, 1938). Thus, one should ascertain the relevance or practicality of the knowledge claims mobilized to accomplish something (Schipper, 2005). A given fact is to be considered as answer to a particular question of fact. The relevance must always form part of the questions involved. Therefore, knowledge management should be reflective - that is, it should be self-conscious of the different aspects of the context, in order to prevent the pitfall of universality (Schipper, 2005).

A common method in knowledge management is to use (financial) reward for knowledge sharing activities in order to enhance communication. However, it may lead to undesired consequence because of the pitfall of universality (Schipper, 2005). Such reward must be used carefully in the context of knowledge management. 


\subsection{Collective Myopia}

As presented, besides general knowledge that is the convergent and cumulative effect of perpetual inquiry, all the people involved in a subject matter have their particular experiences which also matter. We have to take into account their multi-perspective experiences because we have different realities of experience. Thus, knowledge responsibility requires that people are eager to learn from each other as well as being willing to criticize all the knowledge claims that are being made (Schipper, 2005). Cooperation and sharing of knowledge can help correct the risks associated with individual work such as overestimation of one's own performance. This attitude of being in the organization is necessary for reciprocal learning.

However, it should be noted that knowledge sharing does not guarantee that high quality knowledge will be attained, because a collective myopia - a kind of unreflective groupthink - can take hold (Schipper, 2005). In such a situation, the possibility of not really exploring different perspectives of the people involved is significant. In order to prevent this, it is important that the first aspect of knowledge responsibility is really active. It is here that the democratic knowledge process in the organization comes into play so that criticisms of the knowledge claims are made irrespective of hierarchical order (Schipper, 2005).

\subsection{Forgotten Absence}

Related to the issue of misplaced universality is the pitfall of forgotten absence (Schipper, 2005). This is the tendency to place symbolic representations (such as file, note, report, etc.) at the center of attention, thereby making appearance replace substance. The possibility of doing so in the organization is high because the representations function can serve as an effective means of communication. The personal involvement in knowledge, its relational character and quality are easily forgotten, because the representation itself is the only thing present

As knowledge is always related to the settlement of a particular situation by a particular inquiry, one way of coping with this pitfall is to contact the original inquirer who created a given symbolic representation. The person may be able and willing to link it with a new situation in which inquiry occurs. This gives the possibility of rethinking the representation, thereby influencing knowledge quality in a positive way (Schipper, 2005). Thus, all knowledge, as outcome of inquiry, is continually renewed.

This pitfall is likely to happen in the case of IT (Schipper, 2005). IT projects are often considered to be a powerful means of knowledge sharing. But only if IT remains embedded in original modes of cooperation, where the people involved are familiar with each other and with the issues concerned and conscious of the pitfall of representation, can we expect something positive to happen (Schipper, 2005).

\section{Conclusion}

Knowledge management has become an important topic in both the academic world and the business environment. Three main schools of thought about knowledge and knowledge management can be identified: positivism, non-positivism, and pluralistic perspective. Their conflicting perspectives about what knowledge is and what knowledge management should do endure without concluding end. Critiques about all these three schools of thought and the negative consequences of their continuing opposition have been pointed out.

This article contributes to the literature by arguing for a different school of thought that helps solve the conflict between existing schools of thought: the pragmatist perspective about knowledge and knowledge management. This perspective bridges the gulf between the existing schools by proposing an encompassing view to eliminate their opposition. It moves beyond the polarization of universal and situated knowledge. Moreover, it does not take a rather simplistic view that see universal and situated knowledge is two separated types interacting with each other along the continuum (Nonaka \& von Krogh, 2009). It sees all knowledge as partly universal and partly situated.

Our discussion of the pragmatist perspective about knowledge and knowledge management is drawn heavily from pragmatist philosophy. Knowledge, for pragmatists, is outcome of inquiry, with the chief value being its usefulness in helping people to better cope with the world or to create better organizations. In light of this perspective, we argued for an approach of knowledge management that can be called reflective knowledge management, which requires knowing people and people in charge of the knowledge management function to have an attitude of being that is called knowledge responsibility. This implies that the organization should be conscious of and try to avoid some risks in managing knowledge: dominant management focus, misplaced universality, collective myopia, and forgotten absence. Knowledge should not be disseminated from a general management perspective and disconnected from real users; it should not be considered as universal and 
applicable to any situation at hand; it should not be simply codified and stored in a database, knowledge must be seen in context and action. Most importantly, people must be eager to learn from each other.

In implementing reflective knowledge management, the organization should be aware of these risks. Employees need to be trained so that misunderstanding about knowledge and knowledge management can be avoided. They should also be encouraged to learn and share knowledge with each other. To this extent, further research is needed to identify effective ways to promote that mindset among employees.

\section{References}

Alavi, M., \& Leidner, D. (2001). Review: knowledge management and knowledge management systems: conceptual foundations and research issues. MIS Quarterly, 25(1), 107-136. http://dx.doi.org/10.2307/3250961

Alvesson, M., \& Karreman, D. (2001). Odd couple: making sense of the curious concept of knowledge management. Journal of Management Studies, 38(7), 995-1018. http://dx.doi.org/10.1111/1467-6486.00269

Aram, J., \& Salipante, P. (2003). Bridging Scholarship in Management: Epistemological Reflections. British Journal of Management, 14(3), 189-205. http://dx.doi.org/10.1111/1467-8551.00374

Avenir, M.-J. (2010). Shaping a constructivist view of organizational design science. Organization studies, 31(9-10), 1229-1256. http://dx.doi.org/10.1177/0170840610374395

Biesta, G., \& Burbules, N. (2007). Pragmatism and Educational Research. Lanham: Rowland and Littlefield Publishers.

Blosch, M. (2001). Pragmatism and organizational knowledge management. Knowledge and Process Management, 8(1), 39-48. http://dx.doi.org/10.1002/kpm.95

Bresnen, M., Edelman, L., Newell, S., Scarbrough, H., \& Swan, J. (2003). Social practices and the management of knowledge in project environments. International Journal of Project Management, 21(3), 157-166. http://dx.doi.org/10.1016/S0263-7863(02)00090-X

Brown, J. S., \& Duguid, P. (2001). Knowledge and organisation: a social practice perspective. Organization Science, 12(2), 198-213. http://dx.doi.org/10.1287/orsc.12.2.198.10116

Cavaleri, S. (2004). Leveraging organizational learning for knowledge and performance. The learning organization, 11(2), 159-176. http://dx.doi.org/10.1108/09696470410521619

Chiva, R., \& Alegre, J. (2005). Organizational learning and organizational knowledge: towards the integration of two approaches. Management learning, 36(1), 49-68. http://dx.doi.org/10.1177/1350507605049906

Cook, S., \& Brown, J. (1999). Bridging epistemologies: the generative dance between organizational knowledge and organizational knowing. Organization Science, 10(4), 381-400. http://dx.doi.org/10.1287/orsc.10.4.381

Corradi, G., Gherardi, S., \& Verzelloni, L. (2010). Through the practice lens: where is the bandwagon of practice-based studies heading. Management Learning, 41(3), 265-283. http://dx.doi.org/10.1177/1350507609356938

De Geus, A. (1988). Planning as learning. Harvard Business Review, 66(2), 70-74.

De Geus, A. (1997). The living company. Boston: Harvard Business Press.

Dewey, J. (1905). The postulate of immediate empiricism. In J. A. Boydston (Ed.), John Dewey: middle works, 1899-1924 (Vol. 3, pp.158-67). Carbondale: Southern Illinois University Press.

Dewey, J. (1916). Democracy and education. New York: The Free Press.

Dewey, J. (1922). Human nature and conduct. New York: Modern Library.

Dewey, J. (1927). The Public and Its Problems. Ohio: Swallow Press/Ohio University Press.

Dewey, J. (1938). Logic: the theory of inquiry. New York: Henry Holt and Company.

Dewey, J. (1958). Experience and nature. USA: Dover.

Dewey, J. (2005). The quest for certainty: a study of the relation of knowledge and action. New York: Minton, Balch \& company.

Donaldson, L. (1996). For positivist organization theory. London: Sage.

Drucker, P. (1997). Post-capitalist society. Oxford: Butterworth-Heinemann. 
Easterby-Smith, M., \& Lyles, M. (2003). Introduction: watersheds of organizational learning and knowledge management. In Easterby-Smith, M. \& Lyles, M., (Eds.), The Blackwell handbook of organizational learning and knowledge management (pp. 1-16). USA: Blackwell Publishing Ltd.

Elkjaer, B. (2004). Organizational learning: the third way. Management learning, 35(4), 419-434. http://dx.doi.org/10.1177/1350507604048271

Fenstermacher, G. D., \& Sanger, M. (1998). What is the significance of John Dewey's approach to the problem of the knowledge?. Elementary School Journal, 98(5), 467-478. http://dx.doi.org/10.1086/461909

Fischer, M., Nackenoff, C., \& Chmielewski, W. (Eds.). (2009). Jane Addams and the Practice of Democray. Urbana and Chicago: University of Illinois Press.

Gherardi, S. (2000). Practice-based theorizing on learning and knowing in organizations. Organization, 7(2), 211-225. http://dx.doi.org/10.1177/135050840072001

Gherardi, S., Nicolini, D., \& Odella, F. (1998). Toward a social understanding of how people learn in the organizations: the notion of situated curriculum. Management Learning, 29(3), 273-297. http://dx.doi.org/10.1177/1350507698293002

Grant, R. M. (1996). Toward a knowledge-based theory of the firm. Strategic Management Journal, 17, 109-122.

Guba, E. G., \& Lincoln, Y. S. (1994). Competing paradigms in qualitative research. In Denzin, N. K. \& Lincoln, Y. S. (Eds.), Handbook of qualitative research (pp. 105-117). London: Sage.

Handley, K., Sturdy, A., Fincham, R., \& Clark, T. (2006). Within and Beyond Communities of Practice: Making Sense of Learning through Participation, Identity and Practice. Journal of Management Studies, 43(3), 641-53. http://dx.doi.org/10.1111/j.1467-6486.2006.00605.x

Hansen, M. T., Nohria, N., \& Tierney, T. (1999). What's Your Strategy for Managing Knowledge?. Harvard Business Review, March-April, 1-10.

Heaton, L., \& Taylor, J. (2002). Knowledge management and professional work. Management Communication Quarterly, 16(2), 210-236. http://dx.doi.org/10.1177/089331802237235

Hislop, D. (2009). Knowledge management in organization. USA: Oxford University Press.

Hislop, D. (2010). Knowledge management as an ephemeral management fashion?. Journal of Knowledge Management, 14(6), 779-790. http://dx.doi.org/10.1108/13673271011084853

Jarzabkowski, P., Mohrman, S., \& Scherer, A. (2010). Organization Studies as Applied Science: The Generation and Use of Academic Knowledge about Organizations Introduction to the Special Issue. Organization Studies, 31(9-10), 1189-1207. http://dx.doi.org/10.1177/0170840610374394

Johnson, J. (2000). Knowledge acquisition and management: perspectives, strategic implications, and extensions to the virtual setting. In Malhotra, Y. (Ed.), Knowledge management and virtual organization. USA: Idea Group Publishing.

Kogut, B., \& Zander, U. (1992). Knowledge of the firm, combinative capabilities and the replication of technology. Organization Science, 3(3), 383-397. http://dx.doi.org/10.1287/orsc.3.3.383

Lave, J., \& Wenger, E. (1991). Situated learning. Legitimate peripheral participation. Cambridge: Cambridge University Press. http://dx.doi.org/10.1017/CBO9780511815355

McElroy, M. (2000). Integrating complexity theory, knowledge management and organizational learning. Journal of knowledge management, 4(3), 195-203. http://dx.doi.org/10.1108/13673270010377652

Metcalfe, M. (2008). Pragmatic inquiry. Journal of the Operational Research Society, 59(8), 1091-1099. http://dx.doi.org/10.1057/palgrave.jors.2602443

Nicolini, D., Gherardi, S., \& Yanow, D. (2003). Introduction: toward a practice-based view of knowledge and knowing in organizations. In Nicolini, D., Gherardi, S. \& Yanow, D. (Eds.), Knowing in organizations: a practice-based approach (pp. 3-31). NY: M.E. Sharpe, Inc.

Nonaka, I. (1994). A dynamic theory of organizational knowledge creation. Organization Science, 5(1), 14-37. http://dx.doi.org/10.1287/orsc.5.1.14 
Nonaka, I., \& von Krogh, G. (2009). Tacit Knowledge and Knowledge Conversion: Controversy and Advancement in Organizational Knowledge Creation Theory. Organization Science, 20(3), 635-652. http://dx.doi.org/10.1287/orsc.1080.0412

Orlikowski, W. J. (1996). Improvising organizational transformation over time: a situated change perspective. Information systems research, 7(1), 63-92. http://dx.doi.org/10.1287/isre.7.1.63

Orlikowski, W. J. (2002). Knowing in practice: enacting a collective capability in distributed organizing. Organization Science, 13(3), 249-273. http://dx.doi.org/10.1287/orsc.13.3.249.2776

Polkinghoime, D. (2000). Psychological inquiry and the pragmatic and hermeneutic traditions. Theory and psychology, 10(4), 453-479. http://dx.doi.org/10.1177/0959354300104002

Roberts, J. (2006). Limits to Communities of Practice. Journal of Management Studies, 43(3), 623-39. http://dx.doi.org/10.1111/j.1467-6486.2006.00618.x

Sanchez, R. (2005). Knowledge management and organizational learning: fundamental concepts for theory and practice. Working paper series, Lund Institute of Economic Research. http://dx.doi.org/10.4324/9780203414002_chapter_8

Schipper, F. (2005). Reflective knowledge management: some considerations. In Linstead, S. \& Linstead, A. (Eds.), Thinking organization (pp.136-156). Oxon, UK: Routledge.

Spender, J. (1996a). Making knowledge the basis of a dynamic theory of the firm. Strategic Management Journal, 17, 45-62.

Spender, J. C. (1996b). Competitive advantage from tacit knowledge? Unpacking the concept and its strategic implications. In Moingeon, B. \& Edmondson, A. (Eds.), Organisational learning and competitive advantage. London: Sage Publications. http://dx.doi.org/10.4135/9781446250228.n4

Taylor, C. (2006). Engaged agency and background in Heidegger. In Guignon, C. B. (Ed.), The Cambridge companion to Heidegger (pp. 202-221). Cambridge: Cambridge University Press. http://dx.doi.org/10.1017/CCOL0521821363.008

Tranfield, D., \& Starkey, K. (1998). The nature, social organization and promotion of management research: Towards policy. British Journal of Management, 9(4), 341-353. http://dx.doi.org/10.1111/1467-8551.00103

Tsoukas, H. (1996). The firm as a distributed knowledge system: a constructionist approach. Strategic management journal, 17, 11-25.

Vera, D., \& Crossan, M. (2003). Organizational learning and knowledge management: toward an integrative framework. In Easterby-Smith, M. \& Lyles, M. (Eds.), The Blackwell handbook of organizational learning and knowledge management. USA: Blackwell Publishing Ltd.

Wenger, E. (2004). Knowledge management as a doughnut: Shaping your knowledge strategy through communities of practice. Ivey Business Journal, January, 1-9.

Wicks, A., \& Freeman, R. E. (1998). Organization studies and the new pragmatism: Positivism, anti-positivism, and the search for ethics. Organization Science, 9(2), 123-140. http://dx.doi.org/10.1287/orsc.9.2.123

Zundel, M., \& Kokkalis, P. (2010). Theorizing as Engaged Practice. Organization Studies, 31(9-10), 1209-1228. http://dx.doi.org/10.1177/0170840610374405 